\title{
KEWENANGAN DINAS PENDAPATAN DAERAH DALAM PENGELOLAAN PERPARKIRAN BERDASARKAN PERDA NOMOR 05 TAHUN 2004 TENTANG PAJAK PARKIR PENGARUHNYA TERHADAP PENINGKATAN PENDAPATAN ASLI DAERAH (PAD) KOTA BANDUNG
}

\author{
Erga Yuhandra \\ Fakultas Hukum Universitas Kuningan \\ ergayuhandra@yahoo.co.id
}

\begin{abstract}
As the main source of local revenue, tax has a very atrategic role for the continuity of development today. Therefore, tax should be managed well and properly. Although problem of general parking has been discussed repetedly, there is no obvius solution to the this problem. The problem of existence of parking on-street generally located in the center of a crowded placa accours because many owners of shopping centre do not provide parking area for vistors. The objective of the research is to know and reviewthe authority of Dispenda in the parking management, the tax management of parking tax by Dispenda and its influence to the increace of the regional income, and the obstacles found in the parking management. The research used by the wraiter in the paper is descriptive analysis, that is illustrating the data concerning a matter that is in progress at a certain place and at a certain time and then it is analyzed. The method is juridical normative method, that is the methode using source of secondary data date consists of legal rule ordered hierarchically: 1945 Constitution, laws, government regulation, and other rule under the law. Secondary legal material is legal material obtained from taxs books, foreign journals, opinions of scholars, legal case. Tertiary legal material is legal material that provides instructions or explanations to the primery or secondary legal materials, such as legal dictionary and encyclopedia. The result of the research shows that Dispenda does not have the authority to determine the amount of parking tariff managed by the privat sector. The management of parking tax is in accordance with applied regulations and it is effective. The obstacles found in parking management are the limitide parking area, the messy parking, and the parking arrangement that is not professional.
\end{abstract}

Key word : Authority, Management, Tax parks

\begin{abstract}
Abstrak
Sebagai sumber utama penerimaan daerah maka pajak mempunyai peranan yang sangat strategis bagi kelangsungan pembangunan dewasa ini. Oleh karena itu pajak harus dikelola dengan baik dan benar. Masalah perparkiran umum di Kota Bandung meski sudah berulang kali jadi pembahasan, namun masih belum ada solusi yang jelas. Tujuan dari
\end{abstract}


penelitian ini adalah untuk mengetahui dan mengkaji kewenangan Dispenda dalam pengelolaan perparkiran. Pengelolaan pajak parkir yang dilakukan oleh Dispenda pengaruhnya terhadap peningkatan PAD dan kendala yang ditemukan dalam pengelolaan perparkiran. Penulis melakukan penelitian, menggunakan spesifikasi penelitian deskriptif analitis yaitu menggambarkan data-data tentang suatu hal yang sedang berlangsung pada tempat tertentu dan pada saat tertentu kemudian dianalisis. Adapun metodenya adalah yuridis normatif yaitu metode yang menggunakan sumber-sumber data sekunder, yaitu terdiri dari aturan hukum yang diurut berdasarkan hierarki mulai dari Undang-Undang Dasar 1945, Undang-Undang, Peraturan Pemerintah, dan aturan lain di bawah undang-undang. Bahan hukum sekunder adalah bahan hukum yang diperoleh dari buku teks, jurnal-jurnal asing, pendapat para sarjana, kasus-kasus hukum. Bahan hukum tersier adalah bahan hukum yang memberikan petunjuk atau penjelasan terhadap bahan hukum primer atau sekunder, seperti kamus hukum, dan ensiklopedia. Hasil penelitian menunjukan, bahwa Dinas Pendapatan Kota Bandung tidak memiliki kewenangan untuk menetapkan besarnya tarif yang dikelola oleh pihak swasta. Pengelolaan pajak parkir di Kota Bandung dilaksanakan oleh Dispenda dalam pelaksanaan pengelolaan pajak parkir sudah sesuai dengan peraturan yang berlaku, pengelolaan pajak parkir sudah efektif. Kendala yang ditemukan dalam pengelolaan perparkiran yaitu terbatasnya lahan parkir, perparkiran yang berantakan, sistem penataan yang tidak profesional.

Kata Kunci : Kewenangan, Pengelolaan, Pajak Parkir

\section{Pendahuluan}

Daerah hukum pelaksanaan otonomi daerah di Indonesia didasarkan atas Pasal 18 ayat (1) Undang-Undang Dasar Negara Republik Indonesia Tahun 1945 sebagai berikut: "Negara Kesatuan Republik Indonesia dibagi atas daerah-daerah provinsi dan daerah provinsi itu dibagi atas kabupaten dan kota, yang tiap-tiap provinsi, kabupaten, dan kota itu mempunyai pemerintahan daerah yang diatur dengan Undang-Undang"1. Selanjutnya

1 Dari ketentuan ini dapat dipahami bahwa : Pertama, NKRI dibagi atas susunan daerahdaerah di bawahnya secara hierarkis, yaitu dibagi atas provinsi, dan provinsi dibagi lagi atas daerah kabupaten dan kota sesuai dengan prinsip pembagian kekuasaan secara vertikal (territorial or regional division of power); Kedua, setiap daerah provinsi dan daerah kabupaten/kota itu mempunyai pemerintahan daerah yang diatur dengan undang-undang. Istilah pemerintahan yang dipergunakan di sini adalah dalam arti luas, yaitu tidak saja menyangkut pemerintahan eksekutif seperti pengertian government 
Pasal 18 ayat (2) menegaskan, bahwa pemerintahan daerah provinsi, kabupaten dan kota mengatur dan mengurus sendiri urusan pemerintahan menurut asas otonomi dan tugas pembantuan. Kemudian, Pasal 18 ayat (5) menyatakan, bahwa pemerintah daerah menjalankan otonomi seluasluasnya, kecuali urusan pemerintahan yang oleh Undang-Undang ditentukan sebagai urusan pemerintah pusat ${ }^{2}$. Undang-Undang Nomor 23 Tahun 2014 tentang Pemerintahan Daerah merupakan landasan yuridis bagi pengembangan otonomi daerah ${ }^{3}$ di Indonesia.

Undang-Undang ini secara substansial yang menyangkut pengertian pemerintahan isinya masih sama dengan Undang-Undang Nomor 12 Tahun 2008. Undang-Undang ini menyebutkan, bahwa pengembangan otonomi pada daerah kabupaten dan kota diselenggarakan dengan memperhatikan prinsip-prinsp demokrasi, peran serta masyarakat, pemerataan, dan keadilan, serta memperhatikan potensi, dan keanekaragaman daerah. ${ }^{4}$ Otonomi yang diberikan kepada daerah kabupaten dan kota dilaksanakan dengan memberikan kewenangan yang luas, nyata, dan bertanggungjawab kepada pemerintah daerah secara profesional. Artinya, pelimpahan kewenangan dari pemerintah pusat kepada daerah akan diikuti oleh

dalam sistem politik di Amerika Serikat yang sangat berbeda dari pengertian government di Inggris yang hanya berkaitan dengan pengertian sempit, yaitu pemerintahan eksekutif saja. Lihat Jimly Asshiddiqie, 2009, Komentar Atas UndangUndang Dasar Negara Republik Indonesia Tahun 1945, Jakarta: Sinar Grafika, hlm. 57.

2 Adrian sutedi, 2008, Hukum Pajak dan Retribusi Daerah, Bogor: Ghalian Indonesia, hlm. 1.

3 Otonomi daerah adalah hak, wewenang, dan kewajiban daerah otonom untuk mengatur dan mengurus sendiri urusan pemerintahan dan kepentingan masyarakat setempat sesuai dengan peraturan perundang-undangan. Secara etimologis, kata otonomi berasal dari bahasa Latin, yaitu "autos" yang berarti "sendiri" dan "nomos" yang berarti "aturan". Amram Muslimin mengatakan bahwa otonomi itu salah satu dari asas-asas pemerintahan negara, di mana pemerintah suatu negara melaksanakan suatu kepentingan umum untuk mencapai tujuan. Di samping itu, Ateng Syafruddin mengemukakan bahwa otonomi mempunyai makna kebebasan atas kemandirian, tetapi bukan kemerdekaan. Kemerdekaan terbatas untuk kemandirian adalah wujud pemberian kesempatan yang harus dipertanggungjawabkan.

4 Lihat Undang-Undang Nomor 23 Tahun 2014 Perubahan Ketiga Atas Undang-Undang Nomor 12 Tahun 2008 tentang Pemerintahan Daerah. 
pengaturan pembagian, dan pemanfaatan sumber daya nasional yang berkeadilan, serta perimbangan keuangan pusat dan daerah. ${ }^{5}$

Sebagaimana yang diketahui bahwa pajak merupakan iuran wajib rakyat kepada negara. Pendapatan dari pajak ini, akan digunakan untuk membiayai kegiatan pemerintahan. Sejak Tahun 1999 pembagian pajak menurut wewenang pemungutan pajak dipisahkan menjadi pajak pusat dan pajak daerah. Pajak pusat yang dipungut oleh pemerintah pusat terdiri dari pajak penghasilan dan pajak Bea pertambahan nilai. Untuk pajak daerah dipungut oleh pemerintah daerah itu sendiri. Dasar dilakukannya pemungutan oleh pemerintah daerah sesuai dengan Undang-Undang Nomor 25 Tahun 1999 (sekarang Undang-Undang Nomor 33 Tahun 2004) tentang Perimbangan Keuangan Antara Pemerintah Pusat dan Pemerintah Daerah mengatakan, bahwa Pemerintah dan masyarakat di daerah dipersilahkan mengurus rumah tangganya sendiri secara bertanggungjawab. Peran pemerintah pusat dalam konteks desentralisasi ini adalah melakukan supervisi, memantau, mengawasi, dan mengevaluasi pelaksanaan otonomi daerah. Melalui otonomi daerah, pemerintah daerah diberikan kewenangan untuk mengatur dan mengurus rumah tangga daerahnya sendiri. Langkahlangkah yang perlu diambil dengan cara menggali segala kemungkinan sumber keuangannya sendiri sesuai dengan dan dalam batas-batas peraturan perundang-undangan yang berlaku.

Untuk merealisasikan pelaksanaan otonomi daerah, sumber pembiayaan pemerintah daerah tergantung pada pengaturan PAD. Hal ini diharapkan dan diupayakan dapat menjadi penyangga utama dalam membiayai kegiatan pembangunan di daerah. Oleh karena itu pemerintah daerah harus dapat mengupayakan peningkatan penerimaan yang berasal dari daerah sendiri, sehingga akan memperbesar tersedianya keuangan daerah yang dapat digunakan untuk berbagai kegiatan pembangunan.

Chabib Soleh, 2010, Pengelolaan Keuangan dan Aset daerah, Bandung: Fokusmedia, Hal. 34. 
Adapun upaya tersebut akan semakin memperbesar keleluasaan daerah untuk mengarahkan penggunaan keuangan dearah sesuai dengan rencana, skala prioritas, dan kebutuhan daerah yang bersangkutan.

Penyelenggaraan pemerintahan di daerah dan peningkatan pelayanan kepada mayarakat serta melaksanakan pembangunan daerah, daerah membutuhkan sumber-sumber penerimaan yang cukup memadai. Sumbersumber penerimaan daerah ini dapat berasal dari bantuan dan sumbangan pemerintah pusat maupun penerimaan yang berasal dari daerah sendiri. Namun, perlu digaris bawahi bahwa tidak semua daerah memiliki kekayaan alam. Hal ini tentu akan membuat daerah yang kaya potensi daerah dan memiliki kekayaan alam akan semakin maju, sehingga akan bertolak belakang dengan daerah yang memiliki potensi yang kurang. Berdasarkan keuangan tersebut pemerintah perlu memberikan jalan keluar agar seluruh daerah yang ada di Indonesia berkembang secara merata.

Di dalam Undang-Undang Nomor 33 Tahun 2004 tentang Perimbangan Keuangan Antara Pemerintah Pusat dan Pemerintah Daerah disebutkan, bahwa sumber pendapatan daerah terdiri dari Pendapatan Asli Daerah (PAD), Bagi Hasil Pajak dan Bukan Pajak. Pendapatan Asli Daerah sendiri terdiri dari : Pertama, Pajak Daerah;Kedua, Retribusi Daerah; Ketiga, Hasil pengelolaan kekayaan daerah yang dipisahkan; Keempat, Lain-lain PAD yang sah. Berdasarkan uraian di atas, Pajak Daerah merupakan salah satu faktor pendukung dalam penyelenggaraan pemerintah daerah, karena pendanaan dan pembiayaan yang dipungut dari sektor pajak sangat diperlukan untuk menunjang kegiatan pembangunan di daerah. Ada beberapa jenis pajak yang masuk ke Kas Dispenda Kota Bandung di antaranya : Pertama, Pajak Hotel; Kedua, Pajak Restoran; Ketiga, Pajak Hiburan; Keempat, Pajak Reklame; Kelima, Pajak Penerangan Jalan; Keenam, Pajak Parkir.

Meski berbagai kendala dan permasalahan masih banyak, Dispenda Kota Bandung berupaya mengatasi segala permasalahan dan menciptakan berbagai strategi guna mengatasinya. Berbagai permasalahan yang selama 
ini terjadi di antaranya kesadaran wajib pajak belum sesuai dengan harapan. Hal tersebut tercermin dengan masih adanya tunggakan, masih terjadinya potensi pajak yang belum terpungut karena kelemahan sistem dan pendekatan dengan meningkatkan tarif pajak sulit untuk dilakukan karena persoalan resistensi/memberatkan masyarakat. Guna mengatasi permasalahan di atas, Dispenda Kota Bandung menerapkan berbagai strategi, di antaranya melakukan sosialisasi kepada wajib pajak dan potensi pajak, menerapkan pola insentif dan disinsentif, penyempurnaan sistem dan prosedur, maksimalisasi pengendalian, dan maksimalisasi eksistensifikasi wajib pajak. ${ }^{6}$ Dinas Pendapatan Daerah Kota Bandung merupakan unsur pelaksana Pemerintah Daerah di bidang pengumpulan dana guna membiayai pembangunan daerah yang salah satu tugasnya adalah melaksanakan kegiatan pemungutan pajak daerah kota serta memberikan pelayanan kepada masyarakat khususnya para wajib pajak dalam melaksanakan tugas dan kewajibannya. Dinas Pendapatan Daerah dalam melaksanakan tugasnya telah menetapkan target tertentu dalam upaya memaksimalkan penerimaan dari sektor pajak parkir. Proses pencapaian target itu sendiri mengalami bebagai hambatan di antaranya adalah kesadaran yang rendah dari wajib pajak dan pelayanan yang diberikan aparat pemungut pajak yang belum maksimal.

Berdasarkan data Dispenda Kota Bandung, hingga saat ini ada 390 titik parkir swasta. Total dari pendapatan pajak parkir pada 2009 yakni Rp 5,7 miliar. Pendapatan tersebut diperoleh dari pembayaran pajak parkir yang ditetapkan sebesar 20\% dari omset per-bulan, Dispenda menargetkan kenaikan mendapatkan pajak parkir pada Tahun 2010 yakni sebesar Rp 7,8 M ( Tujuh koma Delapan Miliar). Selain menetapkan target, untuk memaksimalkan penerimaan dari sektor pajak parkir diperlukan juga pengendalian internal yang baik. Pengendalian internal sebagai alat bantu

6 Rizal Aprizal, 2008, Guna Mendukung Pembangunan Kota Bandung Dispenda Berupaya Capai Target Pajak", Bandung: Progresif Jaya, hal. 1. 
untuk mengurangi terjadinya penyimpangan dalam pelaksanaan pemungutan pajak daerah khususnya pajak parkir.

\section{Perumusan Masalah}

Berdasarkan latar belakang masalah di atas, terdapat beberapa permasalahan yang dapat dirumuskan sebagai berikut :

1. Bagaimana kewenangan Dispenda dalam pengelolaan perparkiran di Kota Bandung?

2. Bagaimana pengelolaan pajak parkir yang dilakukan Dispenda Kota Bandung dikaitkan terhadap peningkatan PAD?

3. Kendala apa saja yang ditemui dalam pengelolaan perparkiran sebagai penghambat peningkatan PAD dan bagaimana solusinya?

\section{Metode Penelitian}

Metode pendekatan yang digunakan dalam penelitian ini adalah metode pendekatan yuridis-normatif yaitu penelitian terhadap masalah dengan melihat dari segi peraturan perundang-undangan yang berlaku. Salah satu kegunaan dari penelitian hukum adalah untuk mengetahui apakah dan bagaimanakah hukum mengatur suatu hal serta bagaimana aturan hukum tersebut diterapkan. ${ }^{7}$ Spesifikasi penelitian yang akan digunakan dalam penelitian ini adalah deskriptif analitis, dimana penelitian ini diharapkan dapat memperoleh gambaran yang jelas, rinci, dan sistematis. Sedangkan dikatakan analitis karena data yang diperoleh akan dianalisis untuk pemecahan terhadap permasalahan sesuai dengan ketentuan hukum yang berlaku. Jenis data, dalam penelitian hukum normatif data yang digunakan adalah data sekunder. Untuk pemecahan isu hukum dan sekaligus memberikan preskripsi mengenai apa yang seyogianya, diperlukan sumbersumber penelitian yang berupa bahan-bahan hukum primer dan bahan

Sunaryati Hartono, 1994, Penelitian Hukum Di Indonesia Pada Akhir Abad Ke-20, Edisi Pertama, Bandung: Alumni, hlm. 140-141. 
hukum sekunder. ${ }^{8}$ Metode Pengumpulan Data, sesuai sumber data yang digunakan data sekunder dalam penelitian ini, maka metode pengumpulan data dilakukan melalui studi kepustakaan dan studi dokumenter yang bertempat di Kantor Dinas Pendapatan Daerah Kota Bandung, Perpustakaan Program Sarjana Universitas Pasundan Bandung, serta Perpustakaan Pribadi yang dimiliki oleh penulis.

\section{Pembahasan}

Pemberian otonomi bukan sekedar pemencaran penyelenggaraan pemerintahan untuk mencapai efisiensi dan efektivitas pemerintahan. Otonomi adalah sebuah tatanan ketatanegaraan (Staatsrechtelijke), bukan hanya tatanan administrasi negara (administratiefrechtelijk). Sebagai tatanan ketatanegaraan, otonomi berkaitan dengan dasar-dasar bernegara dan susunan organisasi negara. ${ }^{9}$ Sebagaimana diketahui selama ini, pemerintah kabupaten banyak bergantung pada pemerintah pusat karena terbatasnya jumlah dana yang telah diatur oleh pemerintah pusat. Adanya ketergantungan pemerintah daerah, sulit untuk mencapai tujuan otonomi daerah, terutama bagi daerah yang kurang berkembang.

Salah satu faktor penting dalam pelaksanaan otonomi daerah ialah menyangkut ekonomi atau keuangan daerah. Dengan adanya kemampuan daerah secara ekonomis, maka daerah dapat berdiri sendiri tanpa ketergantungan dengan pusat. Agar pelaksanaan tugas otonomi dapat berjalan dengan baik, yang perlu diperhatikan ialah sumber pendapatan daerah, teknologi, struktur organisasi pemerintahan daerah, dukungan hukum, perilaku masyarakat, dan faktor kepemimpinan.

Pendapatan asli daerah merupakan tulang punggung pembiayaan daerah. Oleh karena itu, kemampuan melaksanakan ekonomi diukur dari

8 Peter Mahmud Marzuki, 2005, Penelitian Hukum, Jakarta: Prenada Media Group, hlm. 141.

9 Bagir Manan, 2001, Menyongsong Fajar Otonomi Daerah, Yogyakarta: Pusat Studi Hukum Fakultas Hukum Universitas Islam Indonesia, hlm. 24. 
besarnya kontribusi yang diberikan oleh pendapatan asli daerah terhadap total APBD. Semakin besar kontribusi yang dapat diberikan terhadap APBD, berarti semakin kecil ketergantungan pemerintah daerah terhadap bantuan pemerintah pusat sehingga otonomi daerah dapat terwujud. ${ }^{10} \mathrm{Di}$ negara mana pun, untuk memenuhi pendapatan negara, upaya yang dilakukan ialah melakukan pemungutan pajak. Sebab, sektor pajak merupakan salah satu sumber pendapatan negara. Di bidang perpajakan dibedakan antara pengertian pajak dengan hukum pajak, meskipun keduanya dalam satu kesatuan. Posisi hukum pajak secara historis atau tradisional termasuk rumpun hukum publik. Dasar konstitusional pemungutan pajak di Indonesia ialah Pasal 23A Undang-Undang Dasar Negara Republik Indonesia Tahun 1945:

"Pajak dan pungutan lain yang bersifat memaksa untuk keperluan negara di atur dengan undang-undang". ${ }^{11}$

Pasal tersebut menghendaki pajak dan pungutan lain yang bersifat memaksa untuk keperluan negara diatur dengan undang-undang. Konsekuensi adanya pasal tersebut, ialah negara memiliki kewajiban membuat aturan hukum yang berbentuk peraturan perpajakan. Aturan hukum di bidang perpajakan yang dibuat oleh negara berdasarkan prosedur yang ditetapkan oleh Undang-Undang Dasar Negara Republik Indonesia Tahun 1945, di mana akhirnya melahirkan hukum pajak nasional. Indonesia

Adrian Sutedi, Hukum Pajak...., Lok. Cit., hlm. 11.

Sesuai dengan prinsip kedaulatan rakyat, yaitu bahwa kekuasaan negara itu dari rakyat, oleh rakyat, dan untuk rakyat dan bahkan bersamarakyat, maka tidak boleh ada pungutan yang dilakukan oleh negara dengan membebani rakyat dengan uang atau halhal yang bernilai uang, kecuali jika hal itu disetujui oleh rakyat sendiri melalui wakilwakilnya di DPR. Tanpa ketentuan undang-undang semua jenis pungutan yang sifatnya memaksa adalah tidak sah dan bertentangan dengan konstitusi. Oleh karena itu, dalam penjelasan Pasal 23 UUD NRI Tahun 1945 diuraikan bahwa "karena penetapan belanja mengenai hak rakyat untuk menentukan nasibnya sendiri, maka segala tindakan yang menempatkan beban kepada rakyat, seperti pajak dan lain-lainnya, harus ditetapkan dengan undang-undang, yaitu dengan persetujuan Dewan Perwakilan Rakyat. Jimly Asshiddiqie, 2011, Komentar Atas Undang-Undang Dasar Negara Republik Indonesia Tahun 1945, Jakarta: Sinar Grafika, hlm. 86. 
sebagai negara kesatuan yang memiliki sistem desentralisasi memiliki dua tingkatan pemerintahan, yaitu pemerintah pusat dan pemerintah daerah. Masing-masing tingkat pemerintah memiliki kewenangan melakukan pungutan pajak. Pajak yang dipungut oleh pemerintah pusat disebut "pajak pusat”, sedangkan pajak yang dipungut oleh pemerintah daerah disebut pajak daerah.

Pendapatan asli daerah merupakan salah satu wujud dari desentralisasi fiskal, untuk memberikan sumber-sumber penerimaan bagi daerah yang dapat digali dan digunakan sendiri sesuai dengan potensinya. Sumber-sumber PAD adalah hasil pajak daerah, hasil retribusi daerah, hasil perusahaan milik daerah, hasil pengelolaan kekayaan daerah, dan pendapatan asli daerah lainnya yang sah. Kewenangan daerah dalam memungut pajak dan retribusi diatur dengan Undang-Undang No. 34 Tahun 2000 tentang Pajak Daerah dan ditindak lanjuti dengan PP No. 66 Tahun 2001 tentang Retribusi Daerah. Berdasarkan undang-undang tersebut, daerah diberikan kewenangan untuk memungut 11 jenis pajak dan 28 jenis retribusi, dengan pertimbangan bahwa jenis pajak dan retribusi tersebut secara umum dipungut dihampir semua daerah dan merupakan jenis pungutan yang baik. Selain itu, pemerintah kabupaten dan kota juga diberi kewenangan untuk memungut jenis pajak dan retribusi lainnya, sesuai kriteria tertentu yang ditetapkan dalam Undang-Undang.

Undang-Undang No. 34 Tahun 2000 telah menetapkan jenis pajak yang dapat dipungut oleh pemerintah provinsi dan jenis pajak yang dipungut oleh pemerintah kabupaten/kota. Pajak provinsi terdiri dari 4 jenis, yaitu sebagai berikut : Pertama, Pajak Kendaraan Bermotor dan Kendaraan di Atas Air (PKB dan KAA); Kedua, Bea Balik Nama Kendaraan Bermotor dan Kendaraan di Atas Air (BBNKB dan BBNKAA); Ketiga, Pajak Bahan Bakar Kendaraan Bermotor (PBBKB); Keempat, Pajak Pengambilan dan Pemanfaatan Air Bawah Tanah dan Air Permukaan (P3ABT ddan AP). Sementara itu, kewenangan pemerintah kabupaten/kota dalam melakukan 
pungutan pajak meliputi ${ }^{12}$ : Pertama, Pajak hotel; Kedua, Pajak restoran; Keempat, Pajak hiburan; Kelima, Pajak reklame; Keenam, Pajak penerangan jalan; ketujuh, Pajak pengambilan bahan galian golongan C; dan Pajak parkir.

Kewenangan dalam penetapan basis pajak serta penetapan jenis pajak dan retribusi masih dinilai rendah, sebagaimana halnya kewenangan daerah dalam penetapan tarif pajak dan retribusi. Penyelenggaraan otonomi daerah dan desentralisasi fiskal, tidak terlepas dari desentralisasi perpajakan mengingat pajak merupakan komponen penting dalam penerimaan daerah. Sebagaimana pendapat Dafflon bahwa (1) setiap pemerintahan mempunyai kewenangan untuk mengenakan atau tidak mengenakan pajak dan berkemampuan untuk membiayai anggarannya secara independen; (2) daerah secara otonom dapat menawarkan jenis pelayanan publik sehingga mempunyai akses langsung kepada masalah perpajakan dan daerah bertanggung jawab dalam pelaksanaannya karena memperhatikan aspirasi masyarakat daerahnya. Salah satu yang harus dipertanggungjawabkan pemerintah kabupaten/kota kepada masyarakat dalam pemberian pelayanan publik adalah kewenangannya dalam penetapan tarif pajak dan retribusi.

1. Kewenangan Dispenda dalam pengelolaan perparkiran di Kota Bandung.

\subsection{Pengertian Pajak Secara Umum}

Sebelum membahas lebih jauh tentang kewenangan Dinas Pendapatan Daerah Kota Bandung dalam hal pengelolaan pajak daerah Khususnya pajak parkir, ada beberapa definisi tentang pajak dan pajak daerah yang perlu jelaskan terlebih dahulu.

12 Lihat Pasal 2 Undang-Undang Nomor 34 Tahun 200 tentang Pajak dan Retribusi Daerah. 
M.J.H. Smeets dalam bukunya De Economische Betekanis der Belastingen, adalah : ${ }^{13}$

"Pajak adalah prestasi kepada pemerintah yang terutang melalui norma-norma umum, dan dapat dipaksakan, tanpa ada kontraprestasi yang dapat ditunjukan dalam hal yang individual, maksudnya adalah untuk membiayai pengeluaran pemerintah".

N.J. Feldmann dalam bukunya De overheidsmiddelen van Indonesia, Leiden, adalah :

"Pajak adalah prestasi yang dipaksakan sepihak oleh dan terutang kepada penguasa (menurut norma-norma yang ditetapkan secara umum), tanpa adanya kontraprestasi, dan semata-mata digunakan untuk menutup pengeluaranpengeluaran umum".

Definisi Soeparman Soemahamidjaja dalam disertasinya yang berjudul “Pajak Berdasarkan Asas Gotong Royong”, Universitas Padjajaran, Bandung :

"Pajak adalah iuran wajib, berupa uang atau barang, yang dipungut oleh penguasa berdasarkan norma-norma hukum, guna menutupi biaya produksi barang-barang dan jasa-jasa kolektif dalam mencapai kesejahteraan umum".

\subsection{Unsur-Unsur Pajak}

Berdasarkan definisi-definisi tersebut dapat disimpulkan, bahwa pajak memiliki unsur-unsur sebagai berikut :

1. Pajak merupakan peralihan kekayaan dari orang atau badan ke pemerintah;

2. Pajak dipungut berdasarkan atau dengan ketentuan Undang-Undang serta aturan pelaksananya, sehingga dapat dipaksakan;

13 R. Santoso Brotodihardjo, 2008, Pengantar Ilmu Hukum Pajak, Bandung: Refika Aditama, hlm. 4. 
3. Dalam pembayaran pajak tidak ditunjukan adanya kontraprestasi langsung secara individual yang diberikan oleh pemerintah pusat atau daerah.

\subsection{Sistem Pemungutan Pajak}

Berkenaan dengan sistem pemungutan pajak, terdapat beberapa sistem, yakni sebagai berikut :

1. Self Assesment suatu sistem pemungutan pajak, di mana wajib pajak menentukan sendiri jumlah pajak yang terutang sesuai dengan ketentuan undang-undang perpajakan. Dalam tata cara ini, kegiatan pemungutan pajak diletakan kepada aktivitas dari masyarakat sendiri.

2. Official Assesment suatu sistem pemungutan pajak, di mana aparatur pajak yang menentukan sendiri (di luar wajib pajak) jumlah pajak yang terutang. Dalam sistem ini, inisiatif sepenuhnya ada pada aparatur pajak, atau kegiatan dalam menghitung dan pemungutan pajak sepenuhnya ada pada aparatur pajak. Sistem ini berhasil dengan baik kalau aparatur perpajakan, baik kualitas maupun kuantitas, telah memenuhi kebutuhan.

3. Witholding System

adalah penghitungan, pemotongan, pembayaran, serta pelaporan pajak yang dipercayakan kapada pihak ketiga oleh pemerintah (semi self assesment).

\subsection{Fungsi Pajak Daerah}

Sementara itu pemerintah daerah dalam melakukan pemungutan pajak harus tetap “ menempatkan” sesuai dengan fungsinya. Adapun fungsi pajak dapat dikelompokan sebagai berikut.

1. Fungsi Budgeteir

Fungsi budgeteir ialah fungsi pajak sebagai alat untuk mengisi kas negara yang digunakan untuk membiayai kegiatan pemerintahan dan pembangunan.

2. Fungsi Regulator

fungsi regulator ialah bila pajak dipergunakan sebagai alat pengatur untuk mencapai tujuan, misalnya pajak 
minimum keras, dimaksudkan agar rakyat menghindari atau mengurangi konsumsi minuman keras, pajak ekspor, dimaksudkan untuk mengekang pertumbuhan ekspor komoditi tertentu dalam rangka menghindari kalangan produk tersebut di dalam negeri.

3. Fungsi Regulerend

fungsi regulerend merupakan fungsi di mana pajak digunakan sebagai alat untuk mencapai tujuan tertentu yang letaknya di luar bidang keuangan.

4. Fungsi Demokrasi

Fungsi demokrasi ialah fungsi yang merupakan salah satu penjelmaan atau wujud sistem gotong royong, termasuk kegiatan pemerintahan dan pembangunan demi kemaslahatan rakyat

5. fungsi Distribusi

Fungsi distribusi ialah fungsi yang lebih menekankan pada unsur pemerataan dan keadilan dalam masyarakat.

\subsection{Pengertian Pajak Daerah}

Pajak daerah yaitu iuran wajib yang dilakukan oleh daerah kepada orang pribadi atau badan tanpa imbalan langsung yang seimbang, yang dapat dipaksakan berdasarkan peraturan perundang-undangan yang berlaku, yang digunakan untuk membiayai penyelenggaraan pemerintah daerah dan pembangunan daerah. ${ }^{14}$ Sedangkan yang dimaksud dengan hukum pajak adalah keseluruhan peraturan yang memberikan wewenang kepada pemerintah untuk mengambil kekayaan seseorang dan menyerahkannya kembali kepada masyarakat melalui kas negara.

\subsection{Ciri-ciri Pajak Daerah}

Untuk mempertahankan prinsip-prinsip tersebut, maka perpajakan daerah harus memiliki ciri-ciri tertentu. Adapun ciri-ciri dimaksud, khususnya yang terjadi di banyak negara sedang berkembang adalah sebagai berikut.

1. Pajak daerah secara ekonomis dapat dipungut, berarti perbandingan antara penerimaan pajak harus lebih

14 Lihat Undang-Undang Nomor 34 Tahun 2000 tentang Pajak dan Retribusi Daerah. 
besar dibandingkan ongkos pemungutannya. Relatif stabil, artinya penerimaan pajak tidak terlalu besar, kadang-kadang meningkat secara drastis, dan adakalanya menurun secara tajam;

2. Tax base-nya harus merupakan perpaduan antara prinsip keuntungan (benefit) dan kemampuan untuk membayar (ability to pay).

\subsection{Cara Penghitungan Pajak Daerah}

Sedangkan cara mengitung besarnya pokok pajak dihitung dengan cara mengalikan tarif pajak dengan dasar pengenaan pajak. Cara penghitungan ini digunakan untuk setiap jenis pajak daerah, yang juga merupakan dasar penghitungan untuk semua jenis pajak pusat. ${ }^{15}$

Pajak Terutang $=$ Tarif Pajak $\mathbf{x}$ dasar pengenaan Pajak

\subsection{Pengertian Pajak Parkir}

Berdasarkan Peraturan Daerah Kota Bandung Nomor 05 Tahun 2004 Pajak Parkir adalah pajak yang dikenakan atas penyelenggaraan tempat parkir diluar badan jalan oleh Orang Pribadi atau Badan, baik yang disediakan berkaitan dengan pokok usaha maupun yang disediakan sebagai suatu usaha termasuk penyediaan tempat penitipan kendaraan bermotor dan garasi kendaraan bermotor yang memungut bayaran ${ }^{16}$. Pajak parkir ini diberikan untuk meningkatkan Pendapatan Daerah, juga kemakmuran rakyat dalam pembangunan daerah. Dalam peraturan pemerintah nomor 65 Tahun 2001 tentang pajak daerah, dijelaskan lebih

15 Marihot P. Siahaan, 2008, Pajak daerah dan Retribusi Daerah, Jakarta: PT Rajagrafindo Persada, hlm.65.

16 Peraturan Daerah Kota Bandung Nomor 13 Tahun 2001 tentang Pajak Parkir Pasal 1 huruf $j$. 
lanjut bahwa penerimaan parkir adalah di luar badan jalan yang disediakan oleh orang pribadi atau badan, baik yang disediakan berkaitan dengan pokok usaha, termasuk tempat penitipan kendaraan bermotor dan garasi kendaraan yang memungut bayaran.

Berdasarkan Peraturan Daerah Kota Bandung Nomor 05 Tahun 2004 Bab 2 Pasal 2, yaitu :

a. Objek Pajak adalah penyelenggara tempat parkir di luar badan jalan, baik yang disediakan berkaitan dengan pokok usaha maupun yang disediakan sebagai suatu usaha, termasuk penyediaan tempat penitipan kendaraan bermotor dan garasi kendaraan bermotor yang memungut bayaran.

b. Klasifikasi tempat parkir sebagaimana dimaksud ayat (1)

Pasal ini, yaitu :

a) Gedung parkir;

b) Peralatan parkir;

c) Garasi kendaraan bermotor yang memungut bayaran;

d) Tempat penitipan kendaraan bermotor.

c. Tidak termasuk Objek Pajak sebagaimana dimaksud pada ayat (1) pasal ini adalah :

(a) Penyelenggaraan tempat parkir oleh Pemerintah Pusat, Pemerintah Provinsi dan Pemerintah Daerah;

(b) Penyelenggaraan parkir oleh kedutaan, konsulat, perwakilan negara asing, dan perwakilan lembaga-lembaga internasional dengan asas timbal balik;

d. Penyelenggaraan tempat parkir di tempat peribadatan dan sekolah serta tempat-tempat lainnya yang diatur lebih lanjut oleh Walikota.

Menurut Pasal 3 Peraturan Daerah Nomor 05 Tahun 2004 Kota Bandung mengenai Subjek dan Wajib Pajak, yaitu :

a. Subjek Pajak adalah orang pribadi atau badan yang melakukan pembayaran atas tempat parkir.

b. Wajib Pajak adalah orang pribadi atau badan yang menyelenggarakan tempat parkir. 


\subsection{Cara Penghitungan Pajak Parkir}

Berdasarkan Peraturan Daerah nomor 05 Tahun 2004, Dasar Pengenaan Pajak Parkir adalah jumlah atau yang seharusnya dibayar atas sewa tempat parkir, sewa garasi dan sewa penitipan kendaraan. Dasar penghitungan dan penetapan pajak berdasarkan tarif pajak, sesuai Peraturan Daerah Nomor 05 Tahun 2004, dimana pengenaan pajak sebesar $20 \%$ dari penerimaan penyelenggaraan, pengusahaan tempat parkir.

Besarnya pokok Pajak Parkir yang terutang dihitung dengan cara mengalikan tarif pajak dengan dasar pengenaan pajak. Secara umum penghitungan Pajak Parkir adalah sesuai dengan rumus berikut

$$
\begin{aligned}
\text { Pajak Terutang }= & \text { Tarif Pajak } \times \text { Dasar Pengenaan Pajak } \\
= & \text { Tarif Pajak } \times \text { Jumlah Pembayaran untuk } \\
& \text { Pemakaian Tempat Parkir }
\end{aligned}
$$

Pemungutan Pajak Parkir tidak dapat diborongkan. Artinya, seluruh proses kegiatan pemungutan Pajak Parkir tidak dapat diserahkan kepada pihak ketiga. Walaupun demikian, dimungkinkan adanya kerja sama dengan pihak ketiga dalam proses pemungutan pajak, antara lain pencetakan formulir perpajakan, pengiriman surat-surat kepada wajib pajak, atau penghimpunan data objek dan subjek pajak. Kegiatan yang tidak dapat dikerjasamakan dengan pihak ketiga adalah kegiatan penghitungan besarnya pajak yang terutang, pengawasan penyetoran pajak, dan penagihan pajak.

Ketersediaan sarana parkir merupakan salah satu hal yang penting sekali diperhatikan dalam proses pembuatan sebuah tempat umum. Penyediaan lahan parkir yang cukup luas akan dapat menampung 
sebagian besar pengunjung tempat tersebut, terutama bagi mereka yang membawa kendaraan bermotor.

Para pengunjung berkendaraan tersebut akan semakin nyaman mengunjungi tempat tersebut, karena mereka tidak perlu berjalan jauh untuk mencapai tempat umum yang mereka tuju. Proses pengaturan ketersediaan dan lokasi parkir bagi kendaraan yang digunakan oleh para pengunjung, merupakan suatu hal yang sangat penting diperhatikan. Setiap pengunjung berkendaraan selalu ingin mendapat kepastian ketersediaan tempat parkir untuk memarkirkan kendaraan mereka, ketika mereka mencapai pintu masuk lokasi parkir. Ketersediaan tempat tersebut seringkali sulit dipastikan, terutama pada tempat-tempat parkir bertingkat. Keadaan tersebut seringkali menyebabkan para pengunjung harus berputar-putar terlebih dahulu untuk mencari apakah masih ada tempat parkir yang tersedia. Apabila mereka menemukan sebuah tempat parkir yang kosong, maka dengan segera mereka memarkirkan kendaraan mereka pada tempat tersebut. Sedangkan apabila mereka tidak menemukan adanya tempat yang kosong, tidak jarang mereka harus keluar kembali dari lokasi tempat parkir tersebut dengan perasaan kecewa. ${ }^{17}$

Pajak parkir yang dibebankan sebesar $20 \%$ oleh Dinas Pendapatan Daerah (Dispenda) Kota Bandung kepada perusahaan pengelola parkir swasta masih terlalu kecil bila dibandingkan dengan pemasukannya. Untuk itu, Pemerintah Kota Bandung seharusnya melakukan pengkajian tentang tarif parkir dan pajak parkir yang dikelola pihak swasta. Menurut anggota Komisi B DPRD Kota Bandung, Oded M. Danial, angka 20\% yang dibebankan kepada perusahaan pengelolaan parkir swasta harus ditingkatkan, tanpa menyebutkan barapa angka idealnya. Terkait hal itu,

17 Djoni Setiawan, Sistem Pengelolaan Parkir dengan Fasilitas Penentuan Lokasi Parkir Terdekat Dengan Pintu Keluar Masuk, 2007, Seminar Nasional Sistem dan Informatika, Bali: 16 November 2007. 
Kepala Dinas Pendapatan Kota Bandung H. Yossi Irianto menyatakan, Pemerintah Kota Bandung tidak memiliki kewenangan untuk mengubah besaran tarif yang dikelola swasta. Hal itu mutlak kewenangan pihak swasta yang mengelola parkir. Kendati demikian, Yossi merasa yakin pihak swasta tidak akan semena-mena menentukan tarif parkir karena pasti melakukan perhitungan sebelumnya. Di sisi lain Yossi menilai besaran pajak yang dibebankan juga sudah cukup besar dan ideal.

\section{Pengelolaan pajak parkir yang dilakukan Dispenda Kota Bandung} dikaitkan terhadap peningkatan PAD.

Masalah yang akan dibahas dalam penelitian ini adalah bagaimana sistem yang diterapkan dalam pengelolaan pajak parkir pada Dipenda (Dinas Pendapatan Daerah) Kota Bandung, apakah tata cara pengelolaan pajak parkir pada Dispenda Kota Bandung sudah sesuai dengan peraturan yang berlaku, Seberapa besar rasio realisasi penerimaan pajak parkir pada emapat tahun anggaran, hambatan yang terjadi dalam pengelolaan pajak parkir, dan strategi aplikatif dalam pengelolaan pajak parkir pada Dispenda Kota Bandung. Pengelolaan Pajak Parkir di Kota Bandung dilaksanakan oleh Dispenda (Dinas Pendapatan Daerah) Kota Bandung. Dalam pelaksanaan pengelolaan pajak parkir sudah sesuai dengan peraturan yang berlaku, pengelolaan pajak parkir sudah efektif, selain itu tingkat pertumbuhan pajak parkir cukup tinggi sehingga prospek mendatang sangat baik. Walaupun sistem pengelolaan sudah baik tetapi masih terdapat hambatan dalam pelaksanaannya.

Hambatan tersebut antara lain masih ada beberapa Wajib Pajak yang menggunakan tanah pribadi dan badan jalan, tetapi belum ada pemilahan antara pajak parkir dan retribusi parkirnya. UPTD (Unit Pelaksana Teknis Dinas) Perparkiran belum menyerahkan seluruh data Wajib Pajak Parkir kepada Dispenda, dan belum seluruh Wajib Pajak parkir terdata dalam Daftar Pengelola Pajak Parkir Kota Bandung. Dengan hambatan tersebut, Dispenda melaksanakan berbagai strategi aplikatif yaitu membentuk cabang 
dinas, membentuk kelompok kerja tim audit, dengan penyelenggaraan pendataan Wajib Pajak dan Observasi lapangan dan strategi penanganan tunggakan. Berdasarkan hasil analisis dan pembahasan serta penelitian, dapat disimpulkan bahwa sistem pengelolaan pajak parkir sudah sesuai dengan peraturan yang berlaku, pengelolaannya sudah efektif walaupun masih terdapat hambatan dalam pelaksanaannya. Dispenda melaksanakan berbagai strategi aplikatif untuk mengatasi berbagai hambatan. Penulis memberikan saran kepada Dispenda atas hasil penelitian dan analisis mengenai Sistem Pengelolaan Pajak Parkir adalah hendaknya Dispenda meningkatkan pendataan obyek pajak parkir baru per wilayah, UPTD Perparkiran segera menyerahkan seluruh data Wajib Pajak Parkir kepada Dispenda, hendaknya ditambah jumlah petugas yang mengurusi pajak parkir, dan perlu meningkatkan kualitas SDM di lingkungan Dinas terkait. ${ }^{18}$

\section{Kendala apa saja yang ditemui dalam pengelolaan perparkiran sebagai penghambat peningkatan PAD dan bagaimana solusinya.}

Lahan parkir yang ada di Kota Bandung semakin menjamur, namun tidak diimbangi dengan luas kantong parkir yang tidak memadai. Banyaknya supermarket, mall, toko dan kios, serta pasar dan swalayan, seolah-olah tidak memperhitungkan untuk membuat kantong-kantong parkir untuk pembeli dan pelanggan yang datang. Jadi hanya memanfaatkan halaman toko (yang umumnya relatif sempit), lebar jalan dan trotoar. Hal ini tentunya menggangu para pengguna jalan dan pelajan kaki. Lahan parkir yang ada di sekitar pusat perbelanjaan dan toko-toko tersebut, serta lahan parkir yang sudah ada di lokasi tertentu. Oleh karena itu, perlu dilakukan pengelolaan, penataan, dan pemantauan lahan parkir yang nantinya bisa

18 Ika Saniyati Rahmaniyah, 20 September 2010, Sistem Pengelolaan Pajak Parkir Pada Dinas Pendapatan Daerah Kota Surakarta, <http: / / www.google.com / internet Address, > diakses Bulan November 2010 Pukul 14. 50 WIB. 
digunakan untuk penataan lahan parkir dan membantu untuk menentukan lokasi lahan parkir yang strategis dan memadai.

Perkembangan dan pertumbukan Kota Bandung semakin pesat. Ditambah pula dengan pertumbuhan penduduk yang semakin cepat, dan tingkat kebutuhan penduduk yang semakin tinggi untuk memenuhi kebutuhan mereka, terutama kebutuhan kendaraan bermotor, baik mobil, motor, sepeda motor listrik, dan lain-lain, untuk kebutuhan akses mereka ke tempat tujuan. Tujuan kelokasi pekerjaan atau kantor, sekolah, dan bahkan ke tempat rekreasi, kini sebagian besar penduduk memiliki kendaraan pribadi untuk dapat langsung menuju ke lokasi-lokasi tersebut tanpa harus menunggu angkutan umum.

Tidak bisa dipungkiri bahwa parkir sangat dibutuhkan dan merupakan bagian dari fasilitas publik yang disediakan di kota. Sehingga, parkir sangat dibutuhkan dan merupakan bagian dari sarana atau fasilitas yang sangat dibutuhkan oleh pengguna kendaraan pribadi, baik mobil atau sepeda motor untuk memarkirkan kendaraannya dalam jangka waktu tertentu untuk menjalankan aktivitas yang lain, misalnya : sekolah, kuliah, bekerja, jalanjalan, hingga berbelanja. Dengan kebutuhan parkir dan kafasitas jalan yang tidak memadai serta pertumbuhan kendaraan yang semakin banyak, maka dibutuhkan pengelolaan lahan parkir yang ada sekarang ini. Selain pengelolaan, juga diperlukan pemantauan lahan parkir yang ada saat ini hingga dikemudian hari. Hal ini sangat berguna untuk memantau perkembangan dan memantau kebutuhan parkir untuk meningkatkan kualitas parkir tanpa harus mengganggu jalan. Cukup sulit memang, namun jika tidak dimulai dari sekarang maka akan menjadi batu sandungan dikemudian hari jika masalah lahan parkir ini tidak diantisifasi dari sekarang.

Kebutuhan penduduk akan kendaraan bermotor ini tidak diikuti dengan sarana dan prasarana infrastruktur yang mendukung, misal lahan parkir, maka akan berdampak buruk pada kota itu sendiri. Karena 
kebutuhan lahan untuk parkir sangat dibutuhkan, selain parkir untuk sekolah, perguruan tinggi, kantor, lembaga pemerintahan, rumah sakit, dan mall, umumnya sudah mampu menyediakan lahan parkir yang cukup untuk menampung kendaraan. Namun tidak semua mall, pusat perbelanjan (pasar dan supermarket), tempat hiburan dan tempat rekreasi, mampu menyediakan lahan untuk parkir kendaraan motor tersebut. Imbasnya, pada sekeliling lokasi yang dituju, umumnya para tukang parkir, baik yang resmi maupun yang tidak resmi, membuat lahan parkir sendiri yaitu dipinggirpinggir jalan, baik di badan jalan hingga trotoar. Pengelolaan lahan parkir yang "dipaksakan rapi” yang memakan badan jalan hingga trotoar. Hal ini tentunya sangat merugikan, karena berakibat pada menurunnya kapasitas jalan, lalu lintas menjadi padat dan terhambat, dan menggangu pengguna jalan lain dan pelajan kaki.

Hampir setiap hari Kota Bandung bergumul dengan masalah kemacetan. Kendaraan yang melintas di jalan raya bergerak secara perlahan karena banyaknya halangan yang menghadang. Kasubdin Lalu Lintas dan Angkutan Umum Dinas Perhubungan (Dishub) Kota Bandung, Prijo Soebiandono, menyebutkan sedikitnya ada 32 penyebab kemacetan di kota ini. Tidak seimbangnya pelebaran jalan dengan jumlah kendaraan yang muncul menjadi faktor penting penyebab kemacetan. Terbatasnya kapasitas yang ada tersebut masih harus berkurang dengan banyaknya kendaraan yang parkir di badan jalan. Tengok saja beberapa pusat keramaian di kota ini, misalnya Alun-alun Bandung, Jln. Oto Iskandar Dinata, Jln. Braga, Jln. Astana Anyar, Jln. Ahmad Yani, Jln. Banceuy, dan masih banyak jalan lain yang menjadi pusat keramaian. Masalah perparkiran di Kota Bandung melibatkan empat instansi pemerintah yang memiliki kewenangan dalam mengatasinya. Instansi tersebut adalah pemerintah kota, dalam hal ini wali kota yang berkoordinasi dengan Dishub, Unit Pengelola Perparkiran (UPP), Satuan Polisi Lalu lintas (Satlantas), dan Satuan Polisi Pamong Praja (Satpol PP) sebagai pelaksana dalam penertiban. 
Namun, dalam praktiknya, minimnya koordinasi di antara instansiinstansi tersebut adalah masalah yang $m$ Keberadaan parkir di badan jalan yang umumnya berlokasi di pusat-pusat keramaian terjadi karena banyak pemilik tempat perbelanjaan yang tidak menyediakan lahan parkir bagi pengunjungnya. Semestinya, pendirian tempat usaha harus proporsional antara kegiatan dan sarana jalan maupun prasarana parkir yang ada. Menurut Kasubdin Perencanaan Dinas Tata Kota Bandung, Asep Supardan, idealnya tiap $60 \mathrm{~m}^{2}$ lahan harus menyediakan area parkir untuk satu mobil. Kenyataannya, hal tersebut masih jarang dipraktikkan di lapangan. Salah satu upaya yang dapat dilakukan Dishub ialah dengan mewajibkan pengusaha menyertakan analisis dampak lalu lintas (andalalin) saat akan memperpanjang izin usahanya sesuai dengan isi Pasal 104 Undang-Undang No.10/2001 tentang Penyelenggaraan Perhubungan di Kota Bandung. Melalui andalalin, Dishub akan memberikan penilaian tentang kelayakan pendirian tempat usaha.

Namun, karena saat ini masih banyak tempat usaha yang belum patuh menyertakan andalalin mereka, akhirnya kendaraan-kendaraan pengunjung tetap diparkir di badan jalan. Di wilayah Kota Bandung, terdapat 235 lokasi yang badan jalannya dapat digunakan untuk parkir dengan posisi tertentu. Hal ini sesuai dengan Keputusan Wali Kota Bandung Nomor 551.22/Kep.1473-Huk/2003 tentang Penetapan Lokasi, Kawasan Lingkungan, dan Posisi Parkir untuk Umum pada Badan Jalan di Wilayah Kota Bandung. Pengelolaan parkir dan pemungutan retribusi di lokasi-lokasi tersebut dilakukan oleh pemerintah kota melalui Unit Pengelola Perparkiran Kota Bandung. Namun, jumlah lokasi dalam SK Wali Kota tersebut sudah tidak cocok dengan jumlah di lapangan, mengingat ada beberapa tempat yang telah dilarang untuk operasi perparkiran.

Akibatnya, jumlah 235 lokasi tersebut kemungkinan besar akan berkurang mengingat sedang dilakukannya revisi terhadap surat keputusan wali kota yang berlaku. Masalah parkir kendaraan yang menjadi salah satu 
faktor kemacetan, menurut UPP, sulit diatasi dengan penambahan lokasi atau perluasan parkir resmi di badan jalan. Istilah perluasan parkir resmi lebih mengacu kepada pengadaan gedung parkir. Menurut Rusmana, parkir di badan jalan cenderung akan dikurangi bahkan dihilangkan untuk mengurangi risiko kemacetan. Sesuai dengan Perda No. 12/2001 tentang Tata Tertib Pengelolaan Perparkiran, jika telah ada gedung, tidak boleh lagi ada aktivitas perparkiran pada badan jalan di depan gedung tersebut. Konsekuensinya, penghilangan parkir di badan jalan tersebut akan menyebabkan berkurangnya kontribusi yang didapat pemerintah dari retribusi. Namun, solusi pendirian gedung-gedung khusus parkir akan membuat perolehan dari retribusi beralih ke sektor pajak. Selama tahun 2007, berdasarkan data Dinas Pendapatan Daerah (Dispenda) Kota Bandung, pajak parkir menyumbangkan $1 \%$ untuk PAD.

Sementara dari retribusi, mampu menyumbang lebih banyak lagi hingga 1,2\%. Total Rp 8,7 miliar yang masuk ke kas daerah, dari retribusi maupun pajak parkir. Menurut Kasubdin Retribusi Dispenda Kota Bandung (demisioner), Roussa Setiawan, potensi pajak dan retribusi parkir sebenarnya lebih besar dari target yang ditetapkan. "Pajak parkir berpotensi hingga kira-kira Rp 6 miliar, tetapi hanya ditargetkan Rp 4 miliar karena ada nilai yang hilang, seperti lahan parkir swasta yang memang tidak terjadi pungutan sehingga tidak termasuk wajib pajak ${ }^{19}$. Adapun kendala yang ditemukan dalam pengelolaan perparkiran sebagai penghambat peningkatan PAD antara lain adalah : Pertama,Terbatasnya lahan parkir; Kedua, Perparkiran yang berantakan; Ketiga, Penataan yang tidak profesional; Keempat, Arus keluar masuk kendaraan belum tertata; Kelima, Laporan/pencatatan keuangan parkir yang kurang terawasi.

Kendala yang harus dihadapi seperti yang telah dijelaskan di atas, membuktikan bahwa pengelolaan lahan parkir, baik oleh tukang parkir

19 Pikiran Rakyat, Benang Kusut Perparkiran, <http: / / www.google.com/ internet Adress, > diakses Bulan Mei 2010, Pukul 18.46. 
resmi dan tidak resmi, memang membuat masalah parkir ini semakin rumit. Rumit dalam hal pengelolaannya, penataannya, hingga pengaturannya. Sehingga pengelolaan yang rutin dan pemantauan perkembangan kawasan parkir ini nantinya bisa membantu untuk penataan kawasan parkir yang bisa membuat nyaman para pengguna jalan dan pemilik kendaraan. Karena lokasi parkir yang strategis, nyaman dan aman tentunya menguntungkan kedua belah pihak tersebut. Di sisi lain, dengan berhasilnya pengelolaan, penataan, dan pemantauan perparkiran ini dapat meningkatkan kualitas pelayanan publik dan memberikan nilai tambah bagi para pengunjung dari luar kota dan dalam kota sendiri.

Carut-marutnya perparkiran umum di Kota Bandung meski sudah berulang kali jadi pembahasan, namun masih belum ada solusi yang jelas. ${ }^{20}$ Berdasarkan penjelasan di atas, maka sudah seharusnya jika permasalahan yang terjadi dicarikan dan diatasi dengan berbagai solusi dan cara yang tepat, sehingga permasalahan yang ada tersebut tidak berlarut-larut dan tidak menjadi bom waktu yang klimaks. Oleh karena itu, dalah hal ini, Pemerintah dan lembaga terkait, terus melakukan kajian, analisis, menyusun, dan merumuskan berbagai solusi untuk mengatasi permasalahan tersebut. Salah satunya adalah melakukan penataan, pembenahan, dan pengelolaan yang baik dalam bidang perparkiran, yang juga bagian dari keutuhan permasalahan lalu lintas. Perparkiran merupakan bagian penting dalam manajemen lalu lintas di kawasan perkotaan seperti Wilayah Kota Bandung karena itu, kebijakan perparkiran perlu dilakukan secara konsisten sehingga seluruh aspek dari kebijakan tersebut di arahkan pada tujuan yang sama. Adapun sasaran utama dari kebijakan parkir sebagai bagian dari kebijakan transportasi, yakni sebagai berikut :

1. Untuk mengendalikan jumlah kendaraan yang masuk pada suatu kawasan;

20 Dadi Mulyadi, Pemkot Bandung Tidak Bisa Pecahkan Masalah Parkir, Kamis, 11 Februari 2010. 
2. Meningkatkan Pendapatan Asli Daerah (PAD) yang dikumpulkan dari pungutan retribusi parkir, dan untuk selanjutnya digunakan untuk kesejahteraan masyarakat melalui pembangunan infraktukstur sarana dan prasarana terkait;

3. Meningkatkan fungsi jalan;

4. Meningkatkan kelancaran dan keselamatan lalu lintas;

5. Mendukung tindakan pembatasan lalu lintas lainnya.

Berdasarkan penjelasan mengenai sasaran utama dari kebijakan parkir sebagai bagian dari kebijakan transportasi di atas, maka sudah seharusnya pelaksanaan implementasi sistem dan manajemen operasional perparkiran harus berjalan dengan baik, efektif, optimal, tepat guna, dan tepat sasaran baik berlaku pada on street parking (tepi badan jalan) maupun sistem off street parking (tempat parkir khusus).

\section{Penutup}

\section{Simpulan}

Tarif pajak ditetapkan dengan peraturan daerah, pengelolaan parkir swasta Dinas Pendapatan Daerah Kota Bandung tidak memiliki kewenangan untuk menetapkan besarnya tarif yang dikelola oleh pihak swasta, hal itu mutlak kewenangan pihak swasta yang mengelola parkir. Kendati demikian, Pemerintah Kota Bandung merasa yakin pihak swasta tidak akan semenamena menaikan tarif parkir karena pasti melakukan perhitungan terlebih dahulu.

Dalam pelaksanaan pengelolaan pajak parkir sudah sesuai dengan peraturan yang berlaku, pengelolaan pajak parkir sudah efektif, selain itu tingkat pertumbuhan pajak parkir cukup tinggi. Berdasarkan data yang diperoleh menunjukan bahwa dari tahun 2007-2008 target pajak parkir telah tercapai sehingga peningkatan Pendapatan Asli Daerah (PAD) meningkat, sedangkan pada tahun 2009-2010 target pajak parkir belum mencapai realisasi yang ditargetkan. 
Adapaun hal yang menjadi kendala dalam pengelolaan Perparkiran yaitu terbatasnya lahan parkir, perparkiran yang berantakan, sistem penataan parkir yang tidak professional, arus keluar masuk kendaraan yang belum tertata, dan laporan keuangan parkir yang kurang terawasi.

\section{Saran}

Sebaiknya pemerintah lebih mengutamakan kenyamanan dan keamanan bagi pengguna jasa parkir dibandingkan dengan menaikan tarif pajak parkir, serta lebih meningkatkan pengelolaan yang baik dan sisitem penataan perparkiran yang profesional.

Ada baiknya selaku pemerintah Dispenda harus lebih gencar dalam mensosialisasikan peraturan daerah tentang pajak paerparkiran, serta meningkatkan pendataan obyek pajak parkir baru per wilayah, UPTD Perparkiran segera menyerahkan seluruh data Wajib Pajak Parkir kepada Dispenda, hendaknya ditambah jumlah petugas yang mengurusi pajak parkir, dan perlu meningkatkan kualitas SDM di lingkungan Dinas terkait.

Penyelenggara Perparkiran, Instansi pemerintah yang memiliki kewenangan harus saling berkoordinasi satu sama lain dalam pengelolaan perparkiran, sehingga maslah perparkiran di Kota Bandung dapat terselesaikan. Selain itu pengelola tempat parkir harus lebih profesional dalam hal pengelolaan, penataan, dan pembenahan yang baik dalam bidang perparkiran, serta menindak tegas oknum petugas parkir ilegal, serta dibutuhkan peran serta masyarakat dalam terciptanya keamanan dan kenyamanan dengan tidak parkir sembarangan di badan jalan. 


\section{DAFTAR PUSTAKA}

\section{Buku}

Adrian sutedi, 2008, Hukum Pajak dan Retribusi Daerah, Bogor: Ghalian Indonesia.

Bagir Manan, 2001, Menyongsong Fajar Otonomi Daerah, Yogyakarta: Pusat Studi Hukum Fakultas Hukum Universitas Islam Indonesia.

Chabib Soleh, 2010, Pengelolaan Keuangan dan Aset daerah, Bandung: Fokusmedia.

Jimly Asshiddiqie, 2009, Komentar Atas Undang-Undang Dasar Negara Republik Indonesia Tahun 1945, Jakarta: Sinar Grafika.

Marihot P. Siahaan, 2008, Pajak daerah dan Retribusi Daerah, Jakarta: PT Rajagrafindo Persada.

Rizal Aprizal, 2008, Guna Mendukung Pembangunan Kota Bandung Dispenda Berupaya Capai Target Pajak", Bandung: Progresif Jaya.

R. Santoso Brotodihardjo, 2008, Pengantar Ilmu Hukum Pajak, Bandung: Refika Aditama.

Sunaryati Hartono, 1994, Penelitian Hukum Di Indonesia Pada Akhir Abad Ke-20, Edisi Pertama, Bandung: Alumni.

Peter Mahmud Marzuki, 2005, Penelitian Hukum, Jakarta: Prenada Media Group.

\section{Jurnal/Makalah/Artikel/Surat Kabar}

Djoni Setiawan, Sistem Pengelolaan Parkir dengan Fasilitas Penentuan Lokasi Parkir Terdekat Dengan Pintu Keluar Masuk, 2007, Seminar Nasional Sistem dan Informatika, Bali: 16 November 2007.

Dadi Mulyadi, Pemkot Bandung Tidak Bisa Pecahkan Masalah Parkir, Kamis, 11 Februari 2010. 
Ika Saniyati Rahmaniyah, 20 September 2010, Sistem Pengelolaan Pajak Parkir Pada Dinas Pendapatan Daerah Kota Surakarta, <http: / / www.google.com / internet Address, > diakses Bulan November 2010 Pukul 14. 50 WIB.

Pikiran Rakyat, Benang Kusut Perparkiran, <http: / / www.google.com/ internet Adress, > diakses Bulan Mei 2010, Pukul 18.46.

\section{Peraturan Perundang-undangan}

Undang-Undang Dasar Negara Republik Indonesia Tahun 1945 Amandemen ke-4

Undang-Undang Nomor 34 Tahun 2000 tentang Pajak Daerah dan Retribusi Daerah

Undang-Undang Nomor 33 Tahun 2004 tentang Perimbangan Keuangan Antara Pemerintah Pusat dan Pemerintah Daerah

Undang-Undang Nomor 23 Tahun 2014 tentang Perubahan Ketiga atas Undang-Undang Nomor 12 Tahun 2008 tentang Pemerintahan Daerah Peraturan Pemerintah Nomor 65 Tahun 2001 tentang Pajak Daerah Peraturan Daerah Kota Bandung Nomor 05 Tahun 2004 tentang Pajak Parkir Peraturan Daerah Kota Bandung Nomor 03 Tahun 2008 tentang Penyelenggara Perparkiran 